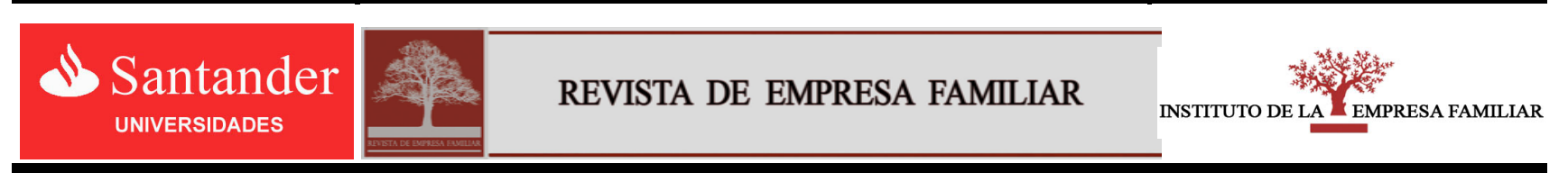

www.revistadeempresafamiliar.uma.es

\title{
Effects of family ownership on SME performance
}

\section{Efectos de la propiedad de la familia en la eficiencia de las Pymes}

\author{
Jesús Herrera Madueño ${ }^{\mathrm{a}, *} \cdot$ Manuel Larran Jorge ${ }^{\mathrm{b}} \cdot$ Gonzalo Sánchez Gardey $^{\mathrm{c}}$ \\ ${ }^{a, b}$ Departamento de Economía Finaciera y Contabilidad. Universidad de Cádiz, 11002 (Spain) \\ ${ }^{c}$ Departamento de Organización de Empresas. Universidad de Cádiz, 11002 (Spain)
}

\author{
D A T O S A R T Í C U L O \\ Historial: \\ Recibido 05-10-2011 \\ Aceptado 16-11-2011

\section{Palabras clave:} \\ Pequeña y Mediana Empresa \\ Eficiencia \\ Empresa familiar \\ Códigos JEL: \\ M1
}

\section{A R T I C LE INFO \\ Article history: \\ Received 05 October 2011 \\ Accepted 16 November 2011}

Keywords:

Small and Medium Sized

Enterprises

Efficiency

Family Firm

JEL codes:

M1

\begin{abstract}
RESUMEN
Este trabajo propone un análisis de las diferencias de eficiencia entre las pequeñas y medianas (Pymes) empresas familiares frente a las no familiares. Las particularidades financieras y organizativas de este tipo de organizaciones han sido discutidas, principalmente, a través de la Teoría de Agencia y la de Costes de Transacción. Debido a la importancia que la variable tamaño tiene sobre estos dos tipos de organizaciones, se ha considerado necesario estratificar la muestra a través de esta variable. De igual forma, las singularidades en la eficiencia de las empresas familiares son analizadas por sectores de actividad. Sin embargo, y contrariamente a lo que se podía esperar, no hubo diferencias en la eficiencia de las Pymes familiares frente a las no familiares.
\end{abstract}

\begin{abstract}
A B S T R A C T
This paper proposes an analysis of efficiency differences between family and non family controlled SME's. The financial and organisational peculiarities of this kind of firms are discussed, drawing on Agency and Transaction Costs theories. Due to the empirically demonstrated importance of size in the differentiation between these two types of organisations, the paper distinguishes between different size segments, in terms of number of employees. Similarly, the singularities in the efficiency of family companies are analysed by distinguishing between sectors of activity. Contrary to what could be expected, no differences in the efficiency of family owned SME's were found. Academic and professional implications of this result are discussed in the last section of the paper.
\end{abstract}

\footnotetext{
Autor de contacto. Tel.: +34956.015.493

Correoselectrónicos: jesus.herrera@uca.es,manuel.larran@uca.es,gonzalo.sanchez@uca.es
} 


\section{Introduction}

Family owned firms are the most common form of business organisation, and they play a vital role in contemporary economies. Nevertheless, most existing studies use large companies as the sample. In this context studies that explicitly investigate the influence of family ownership on the performance of small and medium sized enterprises remain sparse (McCann III, León and Halley Jr., 2001; McConaughy, Matthews and Fialko, 2001; Lee, 2004; Chu, 2009). Several authors have indicated the need to make a more thorough analysis of the strategic and competitive characteristics of small and medium family firms, as well as the factors that condition them in both financial and economic terms (Westhead and Cowling, 1996 and 1997; Scholes, Wright, Westhead and Bruining, 2010). Authors as Stoy (1992), Binder (1994) or Schulze et al. (2001) have firmly encouraged comparative research as the best way to identify their distinctive features. The empirical analysis presented by Lee (2004) represents an interesting contribution in this sense. Comparing financial and operational performance between family and non-family firms, he reached the conclusion that family ownership and management has a positive influence, enhancing cost efficiency and return on investments. This was confirmed in so far as large firms, but as Lee (2004) himself pointed out "the question of whether families also enhance the relative performance of small businesses should be an interesting topic for future research".

In light of this, our paper proposes an analysis of efficiency differences between SME's family and non family controlled SME's. To do so, we draw on previous theoretical research on family firms, to discuss the financial and organisational peculiarities of this kind of firm (Westhead and Cowling, 1997; McConaughy, Walker, Henderson and Mishra, 1998, McConaughy et al. 2001; Anderson y Reeb, 2003). Due to the empiricallydemonstrated importance of size in the differentiation between these two types of organisations (Daily and Dollinger, 1991; Westhead and Cowling, 1998; Anderson and
Reeb, 2003), we will distinguish between different size segments, in terms of number of employees. Similarly, the singularities in the efficiency of family companies will also be analysed by distinguishing between sectors of activity.

This paper is structured as follows. First, the literature in family business performance is reviewed and the possible explanations for the conflicting results are discussed. This is followed by the research methods, where the sample, data collection and the measure are also introduced. The next section is devoted to the presentation of results. Finally, the article ends with the conclusion, discussion and future development of this study.

\section{Concept of family firm}

Previous to the empirical analysis, it is necessary to clarify what we understand by family firm. Although there is no general consensus in the literature with regard to their conceptualisation (Handler, 1989; Westhead and Cowling, 1996 and 1997; Neubauer and Lank, 1998), the different definitions that scholars have proposed can be grouped, following Handler (1989), into three widely used definition criteria. First, there is a large number of works that define family firms as those organisations the majority of whose stock belongs to the members of one family (Donckels and Fröhlich, 1991). Other authors, on the contrary have preferred to take a more subjective point of view linked to the perception of the business as a "family business" (Gasson, Crow, Errigton, Hutson, Marsden and Winter, 1988). Thirdly, the family business has also been conceptualised according to who really is in control, taking into account the extent to which management of the business is in the hands of the members of a single family (Daily and Dollinger, 1992). In this work, the concept of what constitutes a family business is based on a single criterion. Following Donckels and Fröhlich (1991) we have opted for the ownership structure as the distinguishing criterion that allows for a wide, more objective 
discrimination than that proposed by Gasson et al. (1988).

\section{The efficiency of family owned SMEs}

Although the effects of ownership structure on business dynamics has attracted academic attention, little has been said about the influence of SME's family participation (Harvey, 1999; McConaughy et al., 2001, Dyer, 2006). From this perspective, differences between family and non-family businesses have been analysed in terms of behaviour and level of professionalisation (Daily and Dollinger, 1992). However, it is more difficult to find works that contrast the impact of this type of ownership structure upon the level of efficiency (Brockhaus, 1994; Dyer and Handler, 1994; Reynolds, 1995), and when works do indeed contrast the above impact, normally the samples used are restricted exclusively to companies that are quoted on the stock market (Stoy, 1992).

Two complementary theoretical frameworks have been traditionally applied to explain the impact of the business' ownership structure upon levels of profitability and efficiency: the Agency Theory and the Transaction Costs Theory (McConaughy et al., 1998 and 2001).

These two approaches share the basic view of a business as a set of contracts that can be formally designed to reinforce efficiency, or implicitly established through informal relationships (Jensen and Meckling, 1976; Fama, 1980; Fama and Jensen, 1983; Jensen, 1986; Eisenhardt, 1989; Shleifer and Vishny, 1989; Agrawal and Knoebel, 1996; Dyer, 2006).

The Agency Theory argues that business efficiency is achieved through establishing efficient contracts between the two subjects involved in what are termed agency relationships: (1) the principal, who commissions the work and (2) the agent, who carries it out (Eisenhardt, 1989). Such contracts are necessary because of the very characteristics of the interaction between the principal and the agent, which takes place in a situation of limited rationality and knowledge asymmetry.
Sometimes these conditions give rise to opportunistic behaviours, motivated not by common goals but by individual interests.

Agency contracts are established precisely to regulate the above relationships and their objective is therefore to palliate the problems arising from the differences in risk aversion between the principal and the agent, their conflicts of interest and the control of the former over the results of the latter's work (Jensen and Meckling, 1976; Eisenhardt, 1989).

In order to design these governing structures, the Theory of Transaction Costs explores the costs associated with the relationships of internal exchange existing between the individuals that take part in the organisation, analysing how they can minimise the problems related to limited rationality and the conflict of interests between the principal and the agent through the establishment of both implicit and explicit contracts (Barringer and Milkovich, 1998).

From what has just been said it follows that problems arising from limited rationality and the lack of alignment of interests that might affect business efficiency will fundamentally occur when there is a clear separation between ownership of the business and its control (Fama, 1980; Fama and Jensen, 1983; Jensen, 1986).

Applying this logic to the particular situation of family businesses has led many authors to conclude that this type of organisation should present relatively higher levels of efficiency justified by the blurring of the roles of principal and agent, fundamentally in those small family listed that are not quoted on the stock market (Stoy, 1992; Chu, 2009).

Basic propositions of the Agency Theory such as those advanced by Jensen and Meckling (1976) and Fama and Jensen (1983) reach the same conclusion, arguing that in family businesses the costs in terms of conflicts of interest should be smaller, as should the level of opportunist agent behaviour with respect to the principal, leading therefore to higher ratios of efficiency (Aronoff and Ward, 1995; Daily and Dollinger, 1992). 
Nevertheless, other empirical studies have reached contradictory results. There is another large group of authors who propose a relatively smaller efficiency within family businesses (Weasthead and Cowling, 1997), and criticise three underlying suppositions present in works previously mentioned. Firstly, Alchian and Woodward (1988) have questioned the fact that the union of ownership and control eliminate agency problems or that these problems are solved efficiently when the roles of principal and agent are blurred. Therefore relationship control mechanisms do not turn out to be unnecessary in family businesses as Schulze, Lubatkin and Dino (2003) demonstrated when they verified that the use of performance-based incentives are not less used in this type of organisation.

Moreover, the opinion that family relationships cancel out conflicts of interest and information asymmetry has also been subject of criticism. Although it has been pointed out that personal conflict might be moderated by close family ties, the empirical evidence shows that this characteristic does not lessen conflicts that are more task-related, which are directly linked to efficiency (Beehr, Drexler and Faulkner, 1997; Davis and Harveston, 2001; Vilaseca, 2002; Schulze, Lubatkin and Dino, 2003b).

Therefore, and assuming the conflict typology advanced by De Dreu and Weingart 2003), we can state that the family nature of a firm has a positive impact upon the degree of "personal conflict", but not upon what is termed "task conflict". Finally, authors such as Gasson et al. (1988), Goffee (1996) and Westhead and Cowling (1997) have also criticised the implicit assumption in many earlier works that profit maximisation is the main objective of family firms.

As demonstrated earlier, and taking the Agency theory as our point of departure, many authors have deduced that efficiency in nonfamily firms can be affected negatively by the fact that those responsible for managing the organisation are motivated by utility functions other than profit maximisation, this latter being the owners' priority.
However, this argument cannot be transferred as a counterpoint to family companies to argue that when the principal and agent is one and the same, profit maximisation is the main driving force behind the business' behaviour (Westhead and Cowling, 1997).

In this regard, Donckels and Fröhlich (1991) verified that the directors of family firms place as their main objectives aspects as the survival of the business and their financial independence, which are ranked higher than the traditional aims of non-family businesses (growth, higher performance and financial profitability).

Continuing this line of reasoning, Daily and Dollinger (1992) demonstrated that there was a greater reluctance towards growth in family businesses, a fact that might be explained by the owners' fear of the family losing control of the organisation and a greater preference for stability (Binder, 1994; Ng and Keasey, 2010).

The importance given to this set of nonfinancial objectives means that family firms are prepared to sacrifice present efficiency in favour of continuity or the guaranteed transmission of the business to future generation (Hay and Morris, 1984).

Based on the previously established, our proposal is:

H.1.: Family firms show higher levels of efficiency, in terms of economic and financial profitability and higher margins than non-family companies.

\section{Empirical analysis}

\subsection{Sample}

The initial sample consisted of 816 Spanish SME's (firms with less than 250 employees). The proportional fixation sampling procedure used, and the fact that they were randomly chosen from the SABI database (Iberian Balance Sheet Analysis System) ensured that the sample was representative of the Spanish business population for a confidence interval of 95 percent, not only as a whole but also in the different segments of sector and size considered (table 1). 
The data necessary for the analysis were extracted via a questionnaire addressed to the company's manager that included items designed to identify the family nature of the business and describe its main structural organisational and strategic characteristics. The financial information was extracted directly from the SABI database that gathers complete annual financial accounts as another as other that was used to evaluate company's efficiency.

\section{Table 1}

Sample distribution by size and sectors of activity.

\begin{tabular}{ccccc}
\hline \multirow{2}{*}{$\begin{array}{c}\text { Sector of } \\
\text { Activity }\end{array}$} & $\begin{array}{c}\text { Size } \\
\text { (number of } \\
\text { workers) }\end{array}$ & $\begin{array}{c}\text { Non } \\
\text { Family } \\
\text { Firms }\end{array}$ & $\begin{array}{c}\text { Family } \\
\text { Firms }\end{array}$ & Total \\
\hline \multirow{3}{*}{ Industry } & -10 employees & 28 & 80 & 108 \\
\cline { 2 - 5 } & $11-50$ employees & 45 & 92 & 137 \\
\cline { 2 - 5 } & $51-249$ employees & 30 & 69 & 99 \\
\hline \multirow{3}{*}{ Building } & -10 employees & 28 & 42 & 70 \\
\cline { 2 - 5 } & $11-50$ employees & 24 & 66 & 90 \\
\cline { 2 - 5 } Services & $51-249$ employees & 13 & 43 & 56 \\
\cline { 2 - 5 } & -10 employees & 29 & 48 & 77 \\
\cline { 2 - 5 } & $11-50$ employees & 29 & 81 & 110 \\
\hline & $51-249$ employees & 23 & 46 & 69 \\
\hline
\end{tabular}

1 Error in each segment (Sector-Size): 10\%

2 Maximum global error in the worst case $(p=q=1 / 2): 14,7 \%$

To explore the relationship between the family nature of a business and its efficiency, considering the lack of consensus in previous empirical research, we analyse if differences do really exist, applying Pearson's $\chi^{2}$ test and ANOVA.

The strength and direction of this relationship will be explored through Kendall's Tau statistic. In order to capture differences in efficiency, and following the recommendations of Stoy (1992) and Westhead and Cowling (1997) of not basing this type of study on uni-dimensional measurements of performance, three different variables will be used.

\subsection{Variables}

Those organisations with a participation of more than 50 percent by a family group have been considered to be family firms. Moreover, in order to incorporate the efficiency variable, we have followed the criterion of using profit- related measurements (Akhigbe and McNulty, 2005), a procedure that enjoys a wide consensus in literature. In this manner we aim to reflect the business' capacity to generate results based on the correct application of a series of resources to the business activity.

Thus defined, profitability is an essential variable for the long-term survival of the organisation that directly determines its competitive capacity. Following Stoy (1992) and Westhead and Cowling's (1997) proposal, we have decided against using a single measurement of efficiency with the aim of capturing real differences in performance and not simply "contextual" or "sample" ones (Westhead and Cowling, 1997: p. 31). Thus, and in order to capture all of the possible variability in efficiency within the sample businesses, three dimensions of profitability have been taken into consideration ${ }^{1}$ :

- Economic Profitability or Investment Profitability, measuring a business' productive efficiency. This variable relates a concept of results before interest with the total capital used without taking into account financing or the origin of capital (owned or borrowed). From an economic point of view, it represents the performance of the totality of the business's investment;

Economic Profitability $=($ Earning before interests and after taxes / Total Assets) * 100

- Financial Profitability: contrasting a concept of business' results (normally yearly results before or after taxes) with shareholder equity. In other words it is the rate at which the business' shareholder equity is remunerated.

Financial Profitability $=$ (Earning Results for the financial year / Stakeholders'Equity) * 100

- Operating Margin Profitability: which relates the operating results obtained by a business in a specific financial year with the operating income achieved in that period.

\footnotetext{
${ }^{1}$ In order to measure these variables, the averages of the data corresponding to financial years 1999 and 2000 were used, these being the latest available complete data available from the SABI database.
} 
Operating Margin Profitability $=($ Operating Results / Operating Income) $* 100$

\section{Results}

Testing the hypothesis concerning the relationship between the family nature of a business and its levels of efficiency was first undertaken applying Pearson's $\chi^{2}$ test and Kendall's Tau.

These statistics enable us to study the link between ordinal variables based on the analysis of their contingency relationships, so it was first necessary to re-encode the continuous efficiency Table 2

Family participation-Efficiency relationship. variables into three categories defined from the sample Medium (Low, Medium and High).

The results of the tests developed indicate, with 90 percent reliability, that there is no type of significant link between family participation and efficiency, revealing a clear independence between the variables (table 2).

This fact can be observed not only in the value of the significance obtained ( $\chi^{2}$ test's $P$ Values are in all cases greater than 0.1 ), but also in the practical coincidence of the expected and observed frequencies in each of the cells in the contingency Table. Kendall's Tau statistic, which might offer the idea of a possible

\begin{tabular}{|c|c|c|c|c|c|c|c|c|c|c|c|c|c|}
\hline \multicolumn{5}{|c|}{ Contingency Table } & \multicolumn{4}{|c|}{ Pearson $\chi^{2}$ Test } & \multicolumn{5}{|c|}{ Kendall's Tau test } \\
\hline & & & $\begin{array}{r}\mathrm{Ma} \\
\mathrm{Fa} \\
\text { Partic } \\
\mathrm{No}\end{array}$ & $\begin{array}{l}\text { rity } \\
\text { iily } \\
\text { pation } \\
\text { Yes } \\
\end{array}$ & & Value & Gl & $\begin{array}{l}\text { Asymp- } \\
\text { totic Sig. } \\
\text { (bilateral) }\end{array}$ & & Value $^{\mathrm{d}}$ & $\begin{array}{l}\text { Asymp- } \\
\text { totic } \\
\text { Standar } \\
\text { d Error }\end{array}$ & $\begin{array}{l}\text { Approx. } \\
\mathrm{T}^{\mathrm{e}}\end{array}$ & $\begin{array}{c}\text { Approx. } \\
\text { Sig. }\end{array}$ \\
\hline \multirow{3}{*}{$\begin{array}{l}\text { Efficiency } \\
\text { by Financial } \\
\text { Profitability } \\
\text { in the last } \\
\text { two years }\end{array}$} & Low & $\begin{array}{l}\text { Tally } \\
\text { Expected }\end{array}$ & $\begin{array}{c}65 \\
70.6\end{array}$ & $\begin{array}{c}175 \\
169.4\end{array}$ & \multirow{3}{*}{$\begin{array}{l}\text { Pearson } \\
\chi^{2} \text { Test } \\
\text { Likehood } \\
\text { Ratio } \\
\text { Linear by } \\
\text { linear } \\
\text { Associa- } \\
\text { tion } \\
\end{array}$} & $1.314^{\mathrm{a}}$ & 2 & 0.519 & \multirow[t]{2}{*}{ Tau-b } & \multirow[t]{2}{*}{-0.044} & \multirow[t]{2}{*}{0.039} & \multirow[t]{2}{*}{-1.145} & \multirow[t]{2}{*}{0.252} \\
\hline & Medium & $\begin{array}{l}\text { Tally } \\
\text { Expected }\end{array}$ & $\begin{array}{c}40 \\
40.0\end{array}$ & $\begin{array}{c}96 \\
96.0\end{array}$ & & 1.313 & 2 & 0.519 & & & & & \\
\hline & High & $\begin{array}{l}\text { Tally } \\
\text { Expected }\end{array}$ & $\begin{array}{c}70 \\
64,4\end{array}$ & $\begin{array}{c}149 \\
154,6\end{array}$ & & 1.311 & 1 & 0.252 & Tau-c & -0.046 & 0.040 & -1.145 & 0.252 \\
\hline \multirow{3}{*}{$\begin{array}{l}\text { Efficiency } \\
\text { by } \\
\text { Economic } \\
\text { Profitability } \\
\text { in the last } \\
\text { two years }\end{array}$} & Low & $\begin{array}{l}\text { Tally } \\
\text { Expected } \\
\end{array}$ & $\begin{array}{c}86 \\
89,1 \\
\end{array}$ & $\begin{array}{c}217 \\
213,9 \\
\end{array}$ & $\begin{array}{l}\text { Pearson } \\
\chi^{2} \text { Test }\end{array}$ & $0.606^{\mathrm{b}}$ & 2 & 0.739 & \multirow{3}{*}{$\begin{array}{l}\text { Tau-b } \\
\text { Tau-c }\end{array}$} & \multirow{2}{*}{-0.027} & \multirow{2}{*}{0.039} & \multirow{2}{*}{-0.699} & \multirow{2}{*}{0.484} \\
\hline & Medium & Expected & 33,8 & 81,2 & \multirow{2}{*}{$\begin{array}{l}\text { Likehood } \\
\text { Ratio } \\
\text { Linear by } \\
\text { linear } \\
\text { Associa- } \\
\text { tion }\end{array}$} & \multirow{2}{*}{$\begin{array}{l}0.601 \\
0.529\end{array}$} & 2 & 0.740 & & & & & \\
\hline & High & $\begin{array}{l}\text { Tally } \\
\text { Expected }\end{array}$ & $\begin{array}{c}56 \\
52,1\end{array}$ & $\begin{array}{c}12 \\
124,9\end{array}$ & & & 1 & 0.467 & & -0.028 & 0.040 & -0.699 & 0.484 \\
\hline \multirow{3}{*}{$\begin{array}{l}\text { Efficiency } \\
\text { by Margin } \\
\text { in the last } \\
\text { two years }\end{array}$} & Low & $\begin{array}{l}\text { Tally } \\
\text { Expected }\end{array}$ & $\begin{array}{c}91 \\
91,5\end{array}$ & $\begin{array}{c}220 \\
219,5\end{array}$ & $\begin{array}{l}\text { Pearson } \\
\chi^{2} \text { Test }\end{array}$ & $0.244^{\mathrm{c}}$ & 2 & 0.885 & Tau-b & -0.009 & 0.039 & -0.231 & 0.817 \\
\hline & Medium & $\begin{array}{l}\text { Tally } \\
\text { Expected }\end{array}$ & $\begin{array}{c}36 \\
37,6\end{array}$ & $\begin{array}{c}92 \\
90,4\end{array}$ & $\begin{array}{l}\text { Likehood } \\
\text { Ratio }\end{array}$ & 0.244 & 2 & 0.885 & & & & & \\
\hline & High & $\begin{array}{l}\text { Tally } \\
\text { Expected }\end{array}$ & 45,9 & 110,1 & $\begin{array}{l}\text { Linear by } \\
\text { linear } \\
\text { Associa- } \\
\text { tion }\end{array}$ & 0.076 & 1 & 0.783 & Tau-c & -0.009 & 0.040 & -0.231 & 0.817 \\
\hline
\end{tabular}

${ }^{\mathrm{a}} 0$ cells $(0.0 \%)$ have an Expected Frequency of less than 5.0, ensuring the correct use of the test.

The minimum expected frequency is 40.00 .

${ }^{\mathrm{b}} 0$ cells $(0.0 \%)$ have an Expected Frequency of less than 5.0. The expected minimum is 33.82 .

${ }^{c} 0$ cells $(0.0 \%)$ have an Expected Frequency of less than 5.0. The expected minimum is 37.65.

${ }^{\mathrm{d}}$ Assuming the alternative hypothesis.

${ }^{\mathrm{e}}$ Using the asymptotic standard error based on the null hypothesis. 
correlation between these ordinal variables, reinforces the conclusion, as all of the relationships analysed turn out to be statistically non-significant.

In order to check that the above results were not biased by the three efficiency categories (High, Medium and Low) that were introduced to make the efficiency measurements ordinal, a variance analysis was carried out.

Table 3

Analysis of a Factor's Variance (Majority Family Participation).

\begin{tabular}{ccccc}
\hline & ANOVA & Variance homogeneity test \\
\hline $\begin{array}{c}\text { Sum of the } \\
\text { squares }\end{array}$ & F & Significance & $\begin{array}{c}\text { Levene } \\
\text { Statistic }\end{array}$ & Significance \\
\end{tabular}

\begin{tabular}{|c|c|c|c|c|c|c|}
\hline \multirow{3}{*}{$\begin{array}{l}\text { Efficiency by financial } \\
\text { profitability in the last } \\
\text { two years }\end{array}$} & Inter-group & 1.011 & 1.311 & 0.253 & .016 & 0.898 \\
\hline & Intra-group & 457.248 & & & & \\
\hline & Total & 458.259 & & & & \\
\hline \multirow{3}{*}{$\begin{array}{l}\text { Efficiency by economic } \\
\text { profitability in the last } \\
\text { two years }\end{array}$} & Inter-group & 0.403 & 0.528 & 0.468 & 0.311 & 0.578 \\
\hline & Intra-group & 452.914 & & & & \\
\hline & Total & 453.318 & & & & \\
\hline \multirow{3}{*}{$\begin{array}{l}\text { Efficiency by margin in } \\
\text { the last two years }\end{array}$} & Inter-group & 0.054 & 0.075 & 0.784 & 0.271 & 0.603 \\
\hline & Intra-group & 426.568 & & & & \\
\hline & Total & 426.622 & & & & \\
\hline
\end{tabular}

In this regard, the ANOVA procedure enabled us to verify that there was no type of Medium significant difference in the efficiency variables (on this occasion considered as continuous) between Family and Non-family Businesses.

Similarly, neither were the variances of both groups found to be significantly different (table 3 ), so also ANOVA shows that this organisational characteristic does not influences efficiency.

Finally, and given the fact that the sample was representative for each sectorial stratum and size, the same analysis was undertaken by activity (industrial, construction and services) and number of employees (less than 10 workers, between 10 and 50 and more than 50 workers). Considering the incidence of these three variables, we tried to explore if family firms with a specific characteristic did indeed present significant differences in efficiency with regard to non-family businesses.

As can be observed in table 4 and 5 , even when these variables were introduced into the analysis, no link between the family nature of the businesses and their efficiency was found. 
Table 4

Family participation-Efficiency relationship by size.

\begin{tabular}{|c|c|c|c|c|c|c|c|}
\hline & \multirow[b]{2}{*}{ Size } & \multicolumn{2}{|c|}{ Pearson's $\chi^{2}$} & \multicolumn{2}{|c|}{ Kendal's Tau } & \multicolumn{2}{|c|}{ ANOVA } \\
\hline & & Value $^{a}$ & Asymptotic sig. & $\begin{array}{l}\text { Tau B } \\
\text { Tau C }\end{array}$ & $\begin{array}{c}\text { Approx. } \\
\text { Significance }\end{array}$ & $\mathrm{F}$ & Sig, \\
\hline \multirow{3}{*}{$\begin{array}{l}\text { Efficiency by } \\
\text { financial } \\
\text { profitability in } \\
\text { the last two } \\
\text { years }\end{array}$} & $\begin{array}{l}\text { Up to } 10 \text { workers } \\
(\mathrm{N}=148)\end{array}$ & 4.241 & 0.120 & $\begin{array}{l}-0.040 \\
-0.042\end{array}$ & $\begin{array}{l}0.622 \\
0.622\end{array}$ & .268 & .605 \\
\hline & $\begin{array}{l}\text { From } 11 \text { to } 50 \\
\text { workers }(\mathrm{N}=263)\end{array}$ & 3.649 & 0.161 & $\begin{array}{l}-0.100 \\
-0.103\end{array}$ & $\begin{array}{l}0.081 \\
0.081\end{array}$ & 2.916 & .089 \\
\hline & $\begin{array}{l}\text { More than } 50 \\
\text { workers }(\mathrm{N}=155)\end{array}$ & $0.173^{\mathrm{a}}$ & 0.917 & $\begin{array}{l}0.013 \\
0.014\end{array}$ & $\begin{array}{l}0.861 \\
0.861\end{array}$ & .024 & .878 \\
\hline \multirow{3}{*}{$\begin{array}{l}\text { Efficiency by } \\
\text { economic } \\
\text { profitability in } \\
\text { the last two } \\
\text { years }\end{array}$} & $\begin{array}{l}\text { Up to } 10 \text { workers } \\
(\mathrm{N}=148)\end{array}$ & 2.238 & 0.327 & $\begin{array}{l}-0.020 \\
-0.021 \\
\end{array}$ & $\begin{array}{l}0.804 \\
0.804 \\
\end{array}$ & .109 & .741 \\
\hline & $\begin{array}{l}\text { From } 11 \text { to } 50 \\
\text { workers }(\mathrm{N}=263)\end{array}$ & 2.612 & 0.271 & $\begin{array}{l}-0.094 \\
-0.094\end{array}$ & $\begin{array}{l}0.114 \\
0.114\end{array}$ & 2.617 & .107 \\
\hline & $\begin{array}{l}\text { More than } 50 \\
\text { workers }(\mathrm{N}=155)\end{array}$ & 1.118 & 0.572 & $\begin{array}{l}0.058 \\
0.057\end{array}$ & $\begin{array}{l}0.438 \\
0.438\end{array}$ & .654 & .420 \\
\hline \multirow{3}{*}{$\begin{array}{l}\text { Efficiency by } \\
\text { margin in the } \\
\text { last two years }\end{array}$} & $\begin{array}{l}\text { Up to } 10 \text { workers } \\
(\mathrm{N}=148)\end{array}$ & 1.494 & 0.474 & $\begin{array}{r}-0.031 \\
-0.031 \\
\end{array}$ & $\begin{array}{l}0.702 \\
0.702 \\
\end{array}$ & 0.238 & 0.626 \\
\hline & $\begin{array}{l}\text { From } 11 \text { to } 50 \\
\text { workers }(\mathrm{N}=263)\end{array}$ & 2.216 & 0.330 & $\begin{array}{l}-0.086 \\
-0.086\end{array}$ & $\begin{array}{l}0.143 \\
0.143\end{array}$ & 2.088 & 0.150 \\
\hline & $\begin{array}{l}\text { More than } 50 \\
\text { workers }(\mathrm{N}=155)\end{array}$ & 3.035 & 0.219 & 0.120 & 0.112 & 2.206 & 0.140 \\
\hline
\end{tabular}

a. 0 cells $(0.0 \%)$ have an Expected Frequency pf less than 5.0, ensuring the correct use of the test.

Table 5

Family participation-Efficiency relationship by sector of activity.

\begin{tabular}{|c|c|c|c|c|c|c|c|}
\hline & \multirow[b]{2}{*}{ Sector } & \multicolumn{2}{|c|}{ Pearson's $\chi^{2}$} & \multicolumn{2}{|c|}{ Kendal's Tau } & \multicolumn{2}{|c|}{$A N O V A$} \\
\hline & & Value $^{a}$ & Asymptotic sig. & $\begin{array}{l}\text { Tau B } \\
\text { Tau C }\end{array}$ & $\begin{array}{c}\text { Approx. } \\
\text { Significance }\end{array}$ & $\mathrm{F}$ & Sig, \\
\hline \multirow{3}{*}{$\begin{array}{l}\text { Efficiency by } \\
\text { financial } \\
\text { profitability in } \\
\text { the last two } \\
\text { years }\end{array}$} & Industrial $(\mathrm{N}=257)$ & 0.341 & 0.843 & $\begin{array}{l}-0.034 \\
-0.035\end{array}$ & $\begin{array}{l}0.571 \\
0.571\end{array}$ & 0.317 & 0.574 \\
\hline & $\begin{array}{l}\text { Construction } \\
(\mathrm{N}=152)\end{array}$ & 0.403 & 0.818 & $\begin{array}{l}-0.046 \\
-0.047\end{array}$ & $\begin{array}{l}0.550 \\
0.550\end{array}$ & 0.375 & 0.541 \\
\hline & Services $(N=172)$ & 0.642 & 0.723 & $\begin{array}{l}-0.051 \\
-0.054\end{array}$ & $\begin{array}{l}0.480 \\
0.480\end{array}$ & 0.498 & 0.481 \\
\hline \multirow{3}{*}{$\begin{array}{l}\text { Efficiency by } \\
\text { economic } \\
\text { profitability in } \\
\text { the last two } \\
\text { years }\end{array}$} & Industrial $(\mathrm{N}=257)$ & 0.326 & 0.850 & $\begin{array}{l}0.007 \\
0.007\end{array}$ & $\begin{array}{l}0.907 \\
0.907\end{array}$ & 0.023 & 0.879 \\
\hline & $\begin{array}{l}\text { Construction } \\
(\mathrm{N}=152)\end{array}$ & 1.767 & 0.413 & $\begin{array}{l}-0.102 \\
-0.103\end{array}$ & $\begin{array}{l}0.188 \\
0.188\end{array}$ & 1.739 & 0.189 \\
\hline & Services $(N=172)$ & 2.001 & 0.368 & $\begin{array}{r}-0.016 \\
-0.016 \\
\end{array}$ & $\begin{array}{l}0.830 \\
0.830\end{array}$ & 0.097 & 0.756 \\
\hline \multirow{3}{*}{$\begin{array}{l}\text { Efficiency by } \\
\text { margin in the } \\
\text { last two years }\end{array}$} & Industrial $(\mathrm{N}=257)$ & 0.941 & 0.625 & $\begin{array}{l}0.056 \\
0.057 \\
\end{array}$ & $\begin{array}{l}0.346 \\
0.346 \\
\end{array}$ & 0.841 & 0.360 \\
\hline & $\begin{array}{l}\text { Construction } \\
(\mathrm{N}=152)\end{array}$ & 2.877 & 0.237 & $\begin{array}{l}0.066 \\
0.063\end{array}$ & $\begin{array}{l}0.395 \\
0.395\end{array}$ & 0.380 & 0.538 \\
\hline & Services $(N=172)$ & 6.249 & 0.044 & -0.178 & 0.013 & 5.976 & 0.016 \\
\hline
\end{tabular}

a. 0 cells $(0.0 \%)$ have an Expected Frequency pf less than 5.0, ensuring the correct use of the test. 
To the contrary, the statistical analysis developed about the efficiency of family businesses validates their underlying null hypothesis. This confirms that "majority family participation" and "efficiency" are completely independent variables. For this reason, it cannot be deduced that family firms enjoy a greater ease in managing internal relationships or less transaction costs, but there is neither evidence that they are less efficient, as previous literature pointed out (Weasthead and Cowling, 1997; Filatotchev, Lien and Piesen, 2005). To the contrary data obtained from Spanish firms point to a third possibility: SME's do not show different levels of efficiency (Castillo and Wakefield, 2006; Weasthead and Howorth, 2006).

This result does not close the analyses of particular aspects of efficiency within family businesses. It is first necessary to explore the same relationships in different national and economic contexts.

Similarly and even considering that different levels of efficiency between family and nonfamily businesses are not to be expected, it would still be interesting to study if profitability in each of the cases is determined by different factors. To do so, it would be particularly interesting to introduce organisational variables (i.e. behaviour, strategy, management professionalization) into the analysis, as potential moderators of the relationship between family participation and efficiency (Daily and Dollinger 1991; Reynolds 1995; Westhead and Cowling 1998; Anderson and Reeb 2003). This kind of analysis could help us to describe the singularities of family owned organisations, and understand the determinants of their efficiency.

\section{Discussion and conclusions}

The purpose of this study sought to provide empirical evidence of the relationship between family ownership and SME's performance. Although the performance implication of family ownership has had important attention in empirical studies, these tend to use large firms, listed or nonlisted, as the research sample. The relationship between family ownership and general performance is still unclear. While Anderson and Reeb (2003), Villalonga and Amit (2006), Lee (2006) or Martínez et al. (2006) argue a positive relationship between family ownership and performance, other authors establish the opposite (Weasthead and Cowling, 1997; Filatotchev et al., 2005). Our result show another possibility, according with Chu (2009), where we did not detect any significant performance differences between family and nonfamily firms.

From a sample of 816 SMEs in Spain. Spanish Sme's representing more 99\% of the country's business, of which $65 \%$, approximately, are family firms. Three different measures of pe were used to test the differences: Economic, Financial and Operating Margin Profitability. Neither of them showed significant results. We conclude that family firms obtain similar performance non family firms ones.

Our contribution of this study is to enhance the Chu's arguments (2009), who sets the distinguishing characteristics between SME's and large firms.

Finally, the principal limitation in this study is relative to the sample. The data was collected in the South of Spain, therefore limiting the possibility of generalizing our findings. For this reason the next step should be conducted to collecting the same data in other parts of Spain in order to increase the external validity of our results. Moreover, we believe that analogous studies should be conducted in countries other than Spain to validity general results.

\section{References}

Agrawal, A. and Knoebel, C.R. (1996). Firm performance and mechanisms to control agency problems between managers and shareholders. Journal of Financial and Quantitative Analysis, 31(3), 377-398.

Akhigbe, A. and McNulty, J. (2005). Profit Efficiency Sources and Differences Among Small and Large U.S. Commercial Banks. Journal of Economics and Finance, 29(3), 289299. 
Alchian, A.A. and Woodward, S. (1988). The firm is dead: long live to the firm, A review of Oliver E. Williamson's The Economic Institutions of Capitalism. Journal of Economic Literature, 26, 65-79.

Anderson, R.C and Reeb, D.M. (2003). Founding-family ownership and firm performance: evidence from the S\&P 500. The Journal of Finance, June.

Aronoff, C. E., and Ward, J.L. (1995). Familyowned Businesses: A Thing of the Past or a Model for the future. Family Business Review, $8,131-151$.

Barringer, M.W., and Milkovich, G.T. (1998). A theoretical exploration of the adoption and design of flexible benefit plans: a case of human resource innovation. Academy of Management Review, 23(2), 305-324.

Beehr, T.A.; Drexler, J.A. and Faulkner, S. (1997). Working in small family businesses: Empirical comparisons to non family businesses. Journal of Organizational Behavior, 18(3), 297-313.

Binder Hamlyn, B. (1994). The Quest for Growth: A survey of UK Private Companies. London: Binder Hamlyn.

Brockhaus, R.H. Sr. (1994). Entrepreneurship and family business research: comparisons, critique and lessons. Entrepreneurship Theory and Practice, 19, 25-38.

Castillo, J., and Wakerfield, M. W. (2006). An exploration of firm performance factor in family business: Do family value only the "bottom line". Journal of Small Business Strategy, 17(2), $37-51$

Chu, W. (2009). The influence of family ownership on SME performance: evidence from public firms in Taiwan. Small Business Economic, 33, 353-373.

Daily, C, and Dolliger, M.J. (1991). Family firms are different. Review of Business, 13, summer/fall, 3-5.

Daily, C. and Dollinger, M. (1992). An empirical Examination of Ownership: Causes and Consequences. Family Business Review, 5, 117-136.
Davis, P.S. and Harveston, P.D. (2001). The phenomenon of substantive conflict in the family firm: a cross generational study. Journal of Small Business Management, 39(1), 14-31.

De Dreu, C.K.W. and Weingart, L.R. (2003). Task versus relationship conflict, team performance, and team member satisfaction: A meta-analysis. Journal of Applied Psychology, $88(4)$.

Donckels, R. and Fröhlich, E. (1991). Are family businesses really different?, European experiences from STRATOS. Family Business Review, 4(2), 149-160.

Dyer Jr., W.G. (2006). Examining the "Family Effect" on Firm Performance. Family Business

Review, 19(4), 253-273.

Dyer Jr., W.G. (2006). Examining the "Family Effect" on Firm Performance. Family Business Review, 19(4), 253-273.

Dyer, W.G., Jr. and Handler, W. (1994). Entrepreneurship an family business: exploring the connections. Entrepreneurship Theory and Practice, 19, 71-83.

Eisenhardt, K.M. (1989). Agency Theory: An Assessment and Review. Academy of Management Review, 14, 57-74.

Fama, E., and Jensen, M. (1983). Separation of Ownership and Control. Journal of Law Economics, 26, 301-325.

Fama, E.F. (1980). Agency Problems and the Theory of the Firm. Journal of Political Economy, 88(2), 288-307.

Filatotchev, I,. Lien, Y. and Piesse, J. (2005). Corporate governance and performance in publicly listed, family-controlled firms: Evidence from Taiwan. Asia Pacific Journal of Management, 22, 257-283.

Gasson, R., Crow, G., Errington, A., Hutson, J., Marsden, T. and Winter, D.M (1988). The farm as a family business: a review. Journal of Agricultural Economics, 39(1), 1-41.

Gersick, K.E., Davis, J.A., Hampton, M. and Lansberg, I. (1997). Generation to Generatio: life cycles of the family business. Boston: Harvard Business School Press. 
Goffee, R. (1996). Understanding family businesses: issues for further research. International Journal of Entrepreneurial Behaviour and Research, 2(1), 36-48.

Handler, W.C. (1989). Methodological issues and considerations in studying family businesses. Family Business Review, 2(3), 257 276.

Harvey, Jr., S.J. (1999). Owner as Manager, Extended Horizons and the Family Firm. International Journal of the Economics of Business, 6(1), 41-55.

Hay, D.A. and Morris, D.J. (1984). Unquoted Companies: Their contribution to the UK Economy. London: McMillan Press.

Jensen, M. C. and Meckling, W. (1976). Theory of the firm: Managerial Behaviour, Agency cost and Ownership Structure. Journal of Financial Economics, 3(4), 305-360.

Jensen, M.C. (1986). Agency costs of free cash flow, corporate finance, and takeovers. American Economics Review, 76(2), 323-329.

Lee, J. (2004). The Effects of Family Ownership and Management on Firm Performance. SAM. Advanced Management Journal, 69(4), 46-53.

McCann III, J.E., León Guerrero, A.Y. and Halley Jr., J.D. (2001). Strategic goal and practice of innovate family businesses. Journal of Small Business Management, 39(1), 50-60.

McConaughy, D.L., Matthews, C.H. and Fialko, A.S. (2001). Founding Family Controlled Firms: Performance, Risk \& Value. Journal of Small Business Management, 39(1), 31-49.

McConaughy, D.L., Walker, M.C., Henderson Jr., G.V. and Mishra, C.S. (1998). Founding Family Firms: Efficiency \& Value. Review of Financial Economics, 7(1), 1-19.

Nenadic, S. (1993). The small family firm in Victorian Britain. Business History, 35, 86-114.

$\mathrm{Ng}$, W. and Keasey, K. (2010). Growing beyond smallness: How do small, closely controlled firms survive? International Small Business Journal. 28(6), 620-630.
Reynolds, P.D. (1995, July). Family firms in the Start up process: preliminary explorations. Annual Meeting of the International Family Business Program Association. Nashville, Tennessee.

Scholes, L., Wright, M., Westhead, P. and Bruining, H. (2010). Strategic changes in family firms post management buyout: Ownership and governance issues. International Small Business Journal, 28(5), 505-521.

Schulze, W.S., Lubatkin, M. H. and Dino, R.N. (2003). Towards a theory of agency and altruism in family firms. Journal of Business Venturing, 18(4), 473-490.

Schulze, W.S., Lubatkin, M. H., Dino, R.N. and Buchholtz, A.K. (2001). Agency relationships in family firms: Theory and evidence. Organization Science, 12(2), 99-116.

Schulze, W.S.; Lubatkin, M.H. and Dino, R.N. (2003b). Exploring the agency consequences of ownership dispersion among the directors of private family firms. Academy of Management Journal, 46(2), 179-194.

Sciascia, S. and Mazzola, P. (2008). Family Involvement in Ownership and Management: Exploring Nonlinear Effects on Performance. Family Business Review, 21(4), 331-345.

Shleifer, A. and Vishny, A. (1989). Management entrenchment: The case of managers specific investments. Journal of Financial Economics, 25, 123-139.

Stoy Hayward (1992). The Perfomance of Family Firms. London: Stoy Hayward.

Vilaseca, A. (2002). The shareholder role in the family business: Conflict of interests and objectives between nonemployed shareholders and top management team. Family Business Review, 15(4), 299-321.

Villalonga, B. and Amit R. (2006). How do family ownership, control and management affect firm value? Journal of Financial Economics, 80, 385-417.

Westhead, P. and Cowling, M. (1996). Demographic contrasts between family and nonfamily unquoted companies in the UK. Working 
paper of the Centre for Small and Medium Sized Enterprises. Coventry: University of Warwick.

Westhead, P. and Cowling, M. (1997).

Perfomance contrasts between family and nonfamily unquoted companies in the UK. International Journal of Entrepreneurial Behavior \& Research, 3(1), 30-52.
Westhead, P. and Howorth, C. (2006). Ownership and management issues associated with family firm performance and company objectives. Family Business Review, 19(4), 301316.

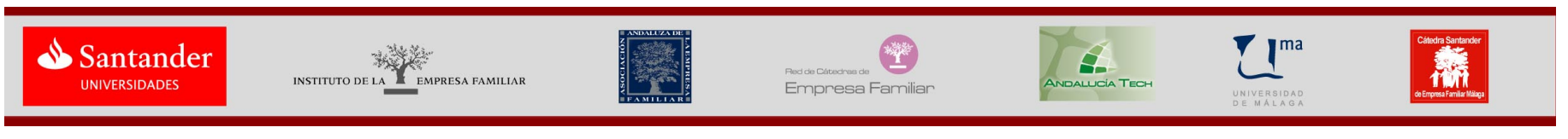

